U.S. DEPARTMENT OF THE INTERIOR

U.S. GEOLOGICAL SURVEY

\title{
GEOLOGIC MAP OF THE SPIRIT LAKE EAST QUADRANGLE, SKAMANIA COUNTY, WASHINGTON
}

\author{
By Russell C. Evarts and Roger P. Ashley
}




\title{
GEOLOGIC MAP OF THE SPIRIT LAKE EAST QUADRANGLE,
}

\author{
SKAMANIA COUNTY, WASHINGTON
}

\author{
By Russell C. Evarts and Roger P. Ashley
}

\section{INTRODUCTION}

The Spirit Lake East quadrangle is situated on the western slope of the Cascade Range in southern Washington approximately $15 \mathrm{~km}$ northeast of Mount St. Helens. Bedrock consists of late Oligocene to early Miocene volcanic and volcaniclastic rocks and shallowlevel plutonic rocks forming the core of the Tertiary Cascade volcanic arc. Surficial deposits include drift representing at least two episodes of alpine glaciation and abundant tephra erupted from Mount St. Helens during the past 40,000 years (Mullineaux and Crandell, 1981; Mullineaux, 1986; Crandell, 1987).

Repeated glacial advances during the Pleistocene sculpted the region into a terrain of considerable relief, but bedrock exposures are generally limited to outcrops in high-gradient streams due to the extensive and heavily vegetated surficial cover. Much of the quadrangle lies within the area of devastation resulting from the May 18, 1980 , eruption of Mount St. Helens (Lipman and Mullineaux, 1981). A laterally directed pyroclastic blastsurge leveled old-growth forest in this area and buried it under a stratigraphically complex blanket, as thick as $1 \mathrm{~m}$, of ash, lapilli, and blocks (Hoblitt and others, 1981; Waitt, 1981; Moore and Sisson, 1981; Fisher and others, 1987). Tephra deposited from the ensuing plinian eruption column and from later eruptions fell mostly eastnortheast of the mountain, covering a band across the southern part of the quadrangle with as much as $20 \mathrm{~cm}$ of ash and pumice lapilli (Waitt and Dzurisin, 1981; Criswell, 1987). Subsequent erosion and salvage logging of the denuded slopes, however, stripped much of this cover as well as older surficial deposits. Slopes as far as $260 \mathrm{~m}$ above the shore of Spirit Lake were largely cleaned of surficial deposits when the rockslide-debris avalanche from the north flank of Mount St. Helens entered the lake on the morning of May 18 (Voight and others, 1981). The resulting exposures of Tertiary bedrock in the Spirit Lake East quadrangle and adjoining areas (Evarts and Ashley, 1993a) are unsurpassed in the western Cascade Range. This area thus provides an exceptional opportunity to examine stratigraphic and structural details of the Tertiary volcanic arc.

\section{ACKNOWLEDGMENTS}

We were ably assisted in the field during the early stages of mapping by Rick Bishop, Mike Covey, Matt Evarts, Jerry Infeld, Scott Petersen, and Carolyn Peterson.
Proficient laboratory support was provided by Joe Ash, Mary Caress, Mike Covey, Jerry Infeld, Rick Pietropaoli, Scott Petersen, Carolyn Peterson, and especially by Rick Bishop. LedaBeth Gray and James G. Smith labored long and hard to coax reliable $\mathrm{K}-\mathrm{Ar}$ and ${ }^{40} \mathrm{Ar} /{ }^{39} \mathrm{Ar}$ dates from recalcitrant rocks. Logistical support provided by Bobbie Myers and the staff of the David A. Johnston Cascades Volcano Observatory after the eruption of Mount St. Helens in 1980 gave us ready access to areas in the southern part of the quadrangle that would have been difficult or impossible to map otherwise. We have benefitted from stimulating and rewarding discussions of Cascadian geology with our U.S. Geological Survey colleagues Donald A. Swanson, James G. Smith, Virgil A. Frizzell, Donal R. Mullineaux, and William E. Scott as well as William M. Phillips and Michael A. Korosec of the Washington State Division of Geology and Earth Resources and Paul E. Hammond of Portland State University. Thoughtful and thorough manuscript reviews by Don Swanson and Jim Smith and comments by Don Mullineaux resulted in considerable improvements in presentation and content.

\section{SUMMARY OF GEOLOGY}

The strata exposed in the Spirit Lake East quadrangle are part of a thick section of middle Tertiary subaerial volcanic rocks that underlies the Mount St. Helens area (Evarts and others, 1987). This section strikes approximately north-south and dips eastward at low to moderate angles, forming the gentle western limb of a major syncline whose axis lies about $5 \mathrm{~km}$ to the east in the French Butte quadrangle (Walsh and others, 1987; Swanson, 1989). The strata are lithologically heterogeneous and stratigraphically complex. Distinctive marker units are absent, and regionally important unconformities have not been recognized in this or adjacent quadrangles; therefore, construction of a formal stratigraphic framework was not attempted, and only lithologic and local informal units are shown on this map. Isotopic age determinations (table 1) are the most valuable data for regional correlation. The age data from this and adjacent areas (Evarts and others, in press) indicate that the volcanic rocks in the Spirit Lake East quadrangle range in age from about 26 to $23 \mathrm{Ma}$ and that intrusive activity continued until about $19 \mathrm{Ma}$. Previous $\mathrm{K}-\mathrm{Ar}$ ages suggesting a younger period of volcanism around 8 to 10 Ma (Evarts and others, 1987) have not been substantiated by recent ${ }^{40} \mathrm{Ar} /{ }^{39} \mathrm{Ar}$ work (see table 1 ). 
Many rocks of the quadrangle appear to represent near-source depositional environments characterized by abundant lava flows, pumiceous pyroclastic rocks, coarsegrained epiclastic deposits, fine-grained intrusions, and zones of hydrothermal alteration (Cas and Wright, 1987; Smith, in press). The thick pile of flows and flow breccia that underlies Bismarck Mountain, for example, probably represents the flank of an andesitic shield similar to that of the Miocene Tieton volcano southeast of Mount Rainier described by Swanson (1966). The dacite of Strawberry Mountain is one the most voluminous accumulations of silicic volcanic rocks in the Washington Cascades (P.E. Hammond, oral commun., 1986) and appears to have constituted a dome field much like that of ancestral Mount St. Helens (Hopson, 1971). Still other probable vents are marked by plugs of flow-banded dacite (Tid) forming conical hills southeast of Harmony Falls and north of Independence Pass, cylindrical plugs of basaltic andesite (Tia) near Curtis Lake, and the network of andesitic dikes and sills (Tia) in lower Bean Creek.
Phaneritic intrusive rocks such as those that make up the sill complex on Windy Ridge (Twr) may exemplify deeper levels of volcanic plumbing systems, although whether they actually vented to the surface is unknown.

Chemical analyses (table 2) reveal that the quadrangle contains a diverse group of volcanic rocks dominated by basaltic andesite and andesite (International Union of Geological Sciences nomenclature of Le Bas and others, 1986; see fig. 1). Basalt (less than 52 weight percent $\mathrm{SiO}_{2}$ ) is rare. Dacite (greater than 63 weight percent $\mathrm{SiO}_{2}$ ) is more abundant than implied by the small number of analyses in table 2, but few silicic rocks are fresh enough for chemical analysis. More than half of the samples are classified as calc-alkaline on the AFM plot (fig. 2) of lrvine and Baragar (1971) whereas most are tholeiitic according to the $\mathrm{FeO} / \mathrm{MgO}$ vs. $\mathrm{SiO}_{2}$ plot (fig. 3) of Miyashiro (1974). The Tertiary rocks tend to be lower in $\mathrm{K}_{2} \mathrm{O}$ than Quaternary volcanic rocks of equivalent $\mathrm{SiO}_{2}$ contents in southern Washington (fig. 4).

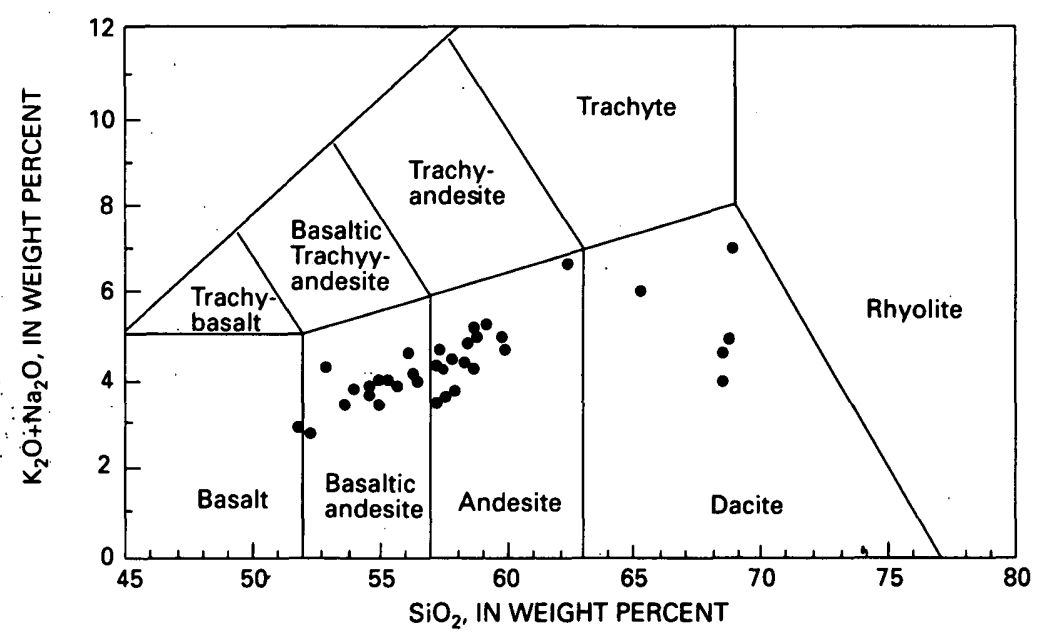

Figure 1. $\mathrm{Na}_{2} \mathrm{O}+\mathrm{K}_{2} \mathrm{O}$ versus $\mathrm{SiO}_{2}$ (recalculated volatile-free) for volcanic and hypabyssal intrusive rocks from Spirit Lake East quadrangle showing classification according to I.U.G.S. (Le Bas and others, 1986).

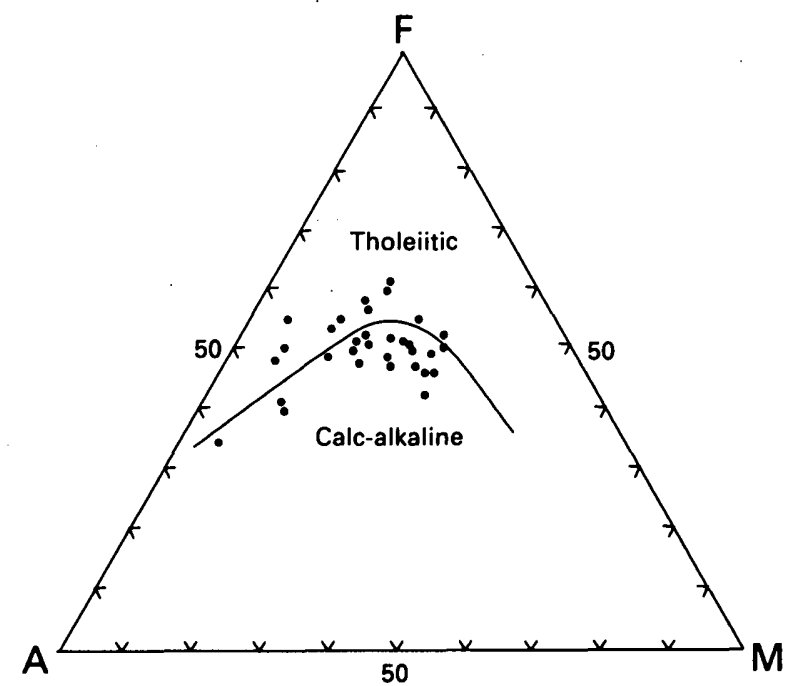

Figure 2. AFM diagram for volcanic and hypabyssal intrusive rocks from Spirit Lake East quadrangle. A, $\mathrm{Na}_{2} \mathrm{O}+\mathrm{K}_{2} \mathrm{O} ; \mathrm{F}, \mathrm{FeO}+\mathrm{Fe}_{2} \mathrm{O}_{3}+\mathrm{MnO} ; \mathrm{M}, \mathrm{MgO}$. Line separating tholeitic and calc-alkaline rocks from Irvine and Baragar (1971). 


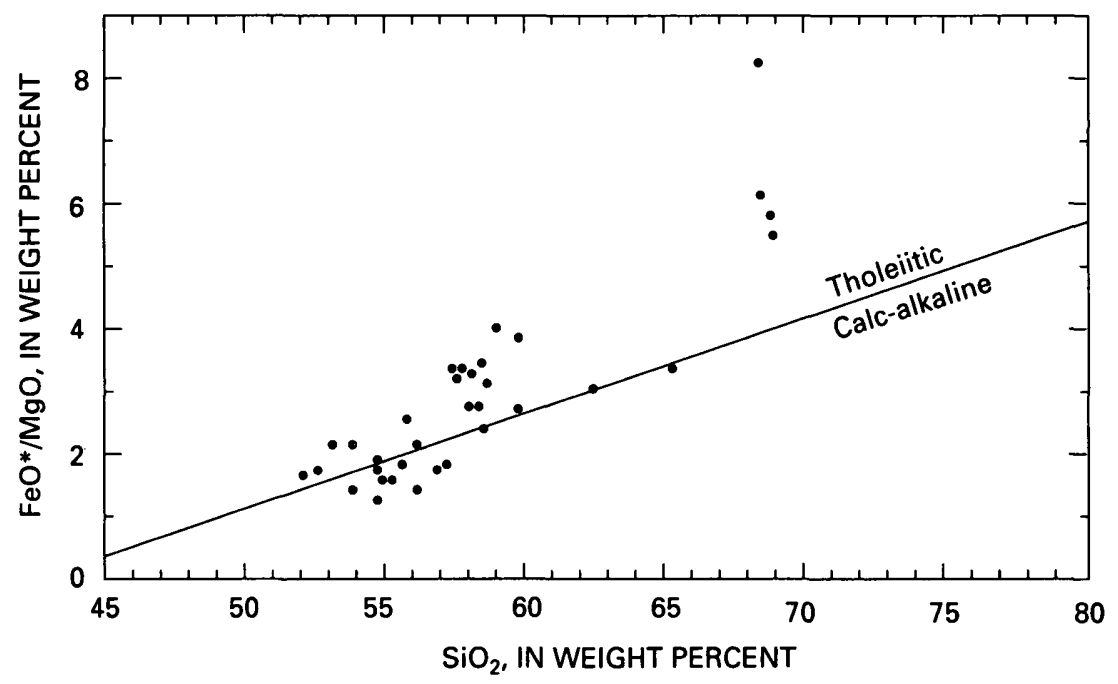

Figure 3. $\mathrm{FeO}^{*} / \mathrm{MgO}$ versus $\mathrm{SiO}_{2}$ (recalculated volatile-free) for volcanic and hypabyssal intrusive rocks from Spirit Lake East quadrangle showing classification into tholeitic and calc-alkaline rocks according to Miyashiro (1974). $\mathrm{FeO}^{*}$, total $\mathrm{Fe}$ as $\mathrm{FeO}$.

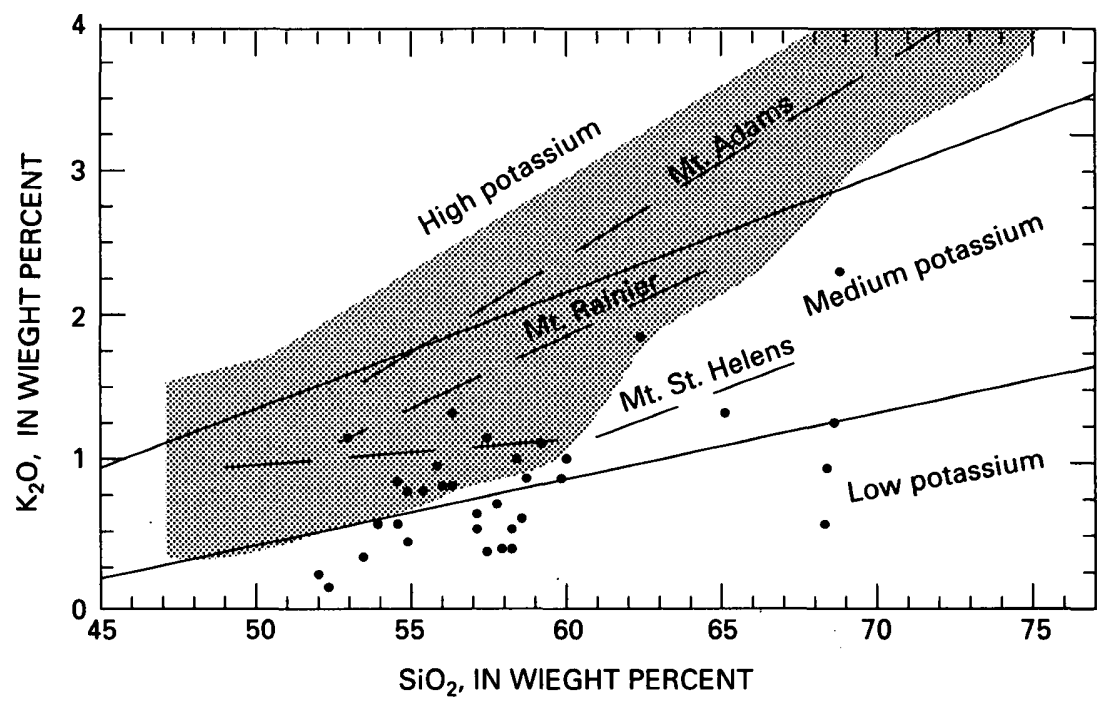

Figure 4. $\mathrm{K}_{2} \mathrm{O}$ versus $\mathrm{SiO}_{2}$ (recalculated volatile-free) for volcanic and hypabyssal intrusive rocks from Spirit Lake East quadrangle. Low-, medium-, and high-potassium fields from Gill $(1981$, p. 6). Shaded area encompasses compositions of Quaternary volcanic rocks, exclusive of major stratovolcanoes, of southern Washington Cascade Range from Hammond and Korosec (1938). Trendlines shown for Quaternary stratovolcanoes Mount Rainier, Mount St. Helens, and Mount Adams based on data in Condie and Swenson (1973), Hildreth and Fierstein (1985), and Smith and Leeman (1987). 
A general westward coarsening of textures in the Spirit Lake pluton (informal name) indicates that it has been tilted to the east along with its host rocks, so folding of the Tertiary section must be younger than $21 \mathrm{Ma}$, the crystallization age of the pluton (table 1). The age of folding is otherwise poorly constrained, and folding may have taken place over an extended period (Evarts and others, 1987).

Faults and shear zones are uncommon. Those that have been observed are subvertical and typically exhibit offsets of no more than a few meters. Generally, the rocks on both sides of faults are identical and the sense of offset cannot be determined. Most faults are flanked by zones of hydrothermally altered rock, or occupied by Tertiary dikes, indicating that they are relatively old. They may represent local small-scale adjustments to movements of magma within Tertiary volcanic centers. The predominance of northwesterly strikes, however, suggests that many of them belong to a regionally extensive set of northwest-trending right-lateral faults and shear zones (and complementary northeast-trending left-lateral shears) that has been recognized east of the Spirit Lake East quadrangle (Swanson, 1989; Swanson and others, 1989).

\section{SPIRIT LAKE PLUTON}

The Spirit Lake pluton is one of several large, epizonal, multiphase, granitic intrusions of Miocene age in the Washington Cascade Range (Fiske and others, 1963; Tabor and Crowder, 1969; Hammond, 1979; Evarts and others, 1987). The pluton underlies an area of about 120 $\mathrm{km}^{2}$, most of which lies outside the Spirit Lake East quadrangle to the north and west; only the southeastern quarter of the intrusion is shown on this map. Along most of the margin of the pluton, contacts with country rock are sharp and steep, and they truncate volcanic stratigraphy at high angles. However, the eastern contact, north of Strawberry Lake, is subhorizontal and cuts across the gently east-dipping volcanic and sedimentary rocks at low to moderate angles (cross section $\left.A-A^{\prime}\right)$; it is interpreted as the roof of the intrusion. The overall configuration of the body at the present level of exposure is that of an eastward-tilted flat-roofed cylinder (Evarts and others, 1987). Locally the contact is more complex, as in the area just north of Spirit Lake where thin sills of granitic rock extend as far as $0.5 \mathrm{~km}$ from the main body of the pluton (cross section $B-B$ ). Probable roof pendants of thoroughly recrystallized volcanic and volcaniclastic rocks crop out near the crest of Goat Mountain, indicating that the configuration of the top of the pluton was at least locally highly irregular.

The pluton consists of three phases, all of which have yielded radiometric ages between 20 and $22 \mathrm{Ma}$. It intrudes rocks as young as 23 to $24 \mathrm{Ma}$. Contacts between phases range from sharp to gradational and are commonly obscured by intense deuteric alteration. Field relations suggest that the quartz diorite phase (Tsqd) is the oldest. The coarser grained and more massive main phase (Tsm), which is texturally and modally variable but has an average composition of granodiorite, constitutes the bulk of the pluton. The granite phase (Tsgr) is slightly younger than the main phase and crops out chiefly near the top of the pluton in the upper Green River area and in the valley of Quartz Creek in the Cowlitz Falls quadrangle to the north (Evarts and Ashley, 1993b).

The pluton may have reached to within $1 \mathrm{~km}$ of the surface. This inference is based on the roughly 2 to 3 million years that separates deposition of the youngest host rocks and crystallization of the intrusion, combined with a typical volcanic accumulation rate for the southern Washington Cascade Range during middle Tertiary time of approximately $300 \mathrm{~m} / \mathrm{m} . y$. (Smith, in press). Widespread granophyric to micrographic textures in rocks of the upper (eastern) part of the pluton further suggest that it may have vented to surface and fed volcanoes, the products of which may be preserved in younger strata exposed east of this quadrangle (see Swanson, 1989).

Smaller phaneritic intrusions of dioritic to granodioritic composition are found east and south of the Spirit Lake pluton. Only the sill complex on Windy Ridge $(24.3 \pm 1.3 \mathrm{Ma})$ has been dated by isotopic techniques. However, because intrusions within the contact aureole of the pluton are metamorphosed, all of these satellitic bodies are inferred to be older than the pluton.

\section{METAMORPHISM}

Tertiary volcanic and intrusive rocks throughout the southern Washington Cascade Range have been overprinted by zeolite-facies burial metamorphism (Fiske and others, 1963; Wise, 1970; Hammond, 1980). Volcanic glass is nearly everywhere replaced by ironbearing smectites that give the rocks their characteristic green colors. Olivine phenocrysts are generally replaced by clots of limonite+smectite, microcrystalline quartz, and (or) carbonate. Orthopyroxene is commonly converted to smectite+titanite, but clinopyroxene remains fresh. Recrystallization of plagioclase is more variable both in extent and mineralogy; partial replacement by albite, calcite, laumontite, stilbite, and various clay minerals is widespread.

A contact-metamorphic aureole extends as far as 4 $\mathrm{km}$ beyond the Spirit Lake pluton. Despite thorough mineralogic reconstitution, primary macroscopic textures are commonly well preserved and permit identification of protoliths. The aureole can readily be subdivided in the field into an inner zone of black, flinty, aphanitic, amphibole-bearing hornfels and an outer zone of green epidote-bearing hornfels (see sketch map).

\section{HYDROTHERMAL ALTERATION AND MINERALIZATION}

The effects of hydrothermal alteration and mineralization directly related to volcanism or to later plutonic activity appear throughout the Spirit Lake East quadrangle. The most conspicuous type of alteration in the volcanic and sedimentary rocks consists of small areas (less than $1 \mathrm{~km}^{2}$ ) that contain erratically distributed bleached limonitic rocks. These altered areas are generally found along faults, shear zones, and dikes, or spatially associated with silicic volcanic rocks. Distribution of alteration was controlled by fractures and permeable clastic beds, and irregular patches of unaltered rock remain within the areas of hydrothermal alteration shown on this map. In hydrothermally altered rocks, primary 
minerals have been totally replaced by carbonate+clay assemblages composed of some combination of kaolinite, montmorillonite, illite, calcite, siderite, dolomite, ankerite, quartz, and limonite. The distribution and mineralogy of these intensely altered areas suggest that they are products of low-temperature, shallow-level, acidic geothermal systems penecontemporaneous with Tertiary volcanism.

Traces of disseminated pyrite are widespread in the quadrangle, but notable occurrences of mineralized rock appear to be most closely associated with granitic intrusive rocks. The most economically significant mineralized area is the Earl (or Margaret) porphyry copper-molybdenum deposit west of Ryan Lake (Hollister, 1979). The deposit underlies an area of roughly $1 \mathrm{~km}^{2}$ within the Spirit Lake pluton and exhibits the classic potassic, phyllic, and propylitic alteration zones typical of porphyry copper systems elsewhere (Beane and Titley, 1981). K-Ar ages of secondary sericite and biotite (table 1; Armstrong and others, 1976) indicate that the deposit formed 4 to 5 million years after crystallization of the pluton, apparently precluding any genetic relationship between the Earl hydrothermal system and the host intrusion. The most likely source of heat and metals for the Earl system is a younger unexposed stock represented by altered dikes of hornblende dacite and quartz porphyry in and around the deposit. Zircon separated from one of the quartz porphyry dikes yielded a concordant $\mathrm{U}-\mathrm{Pb}$ age of 19.0 $\pm 0.1 \mathrm{Ma}$ and fission-track age of $18.8 \pm 0.6 \mathrm{Ma}$ (table 1; Evarts and others, in press).

Elsewhere in the Spirit Lake pluton and adjacent hornfels, minor pyrite is common as thin fracture coatings and replacements of primary mafic silicate and $\mathrm{Fe}-\mathrm{Ti}$ oxide minerals. Preferential weathering of clay-rich supergene alteration zones adjacent to mineralized joints is responsible for a set of prominent northeast-trending topographic lineaments between Spirit Lake and Green River. Sulfides in these occurrences, as well as in the Earl deposit, are commonly accompanied by fine-grained black tourmaline.

A zone of scattered northwest-trending quartz-pyrite veins extends across the center of the quadrangle from the valley of Green River near Ryan Lake to the upper Clearwater drainage basin. A set of similar veins, with a northeasterly trend, crops out west of Ryan Lake. Most contain chalcopyrite, and several contain sphalerite and galena as well. Shearing and brecciation along the veins is common. Although many of these occurrences were worked in the 1890's and early 1900's (Moen, 1977), the only recorded production came from the Sweden Mine, located on a northwest-trending vein that is now beneath the surface of the north end of Spirit Lake. The distribution of these veins peripheral to the Earl deposit suggests that they may be products of the same hydrothermal system. Some occurrences outside of the Spirit Lake pluton, however, display mineralogy compatible with formation during contact metamorphism of their host rocks, so these veins could be coeval with crystallization of the pluton.

\section{REFERENCES CITED}

Armstrong, R.L., Harakal, J.E., and Hollister, V.F., 1976, Age determination of late Cenozoic porphyry copper deposits of the North American Cordillera: Transactions of the Institution of Mining and Metallurgy, section B, p. B239-B244.

Barnosky, C.W., 1984, Late Pleistocene and early Holocene environmental history of southwestern Washington State, U.S.A.: Canadian Journal of Earth Sciences, v. 21, p. 619-629.

Beane, R.E., and Titley, S.R., 1981, Porphyry copper deposits: Part II. Hydrothermal alteration and mineralization, in Skinner, B.J., ed., Economic Geology, Seventy-Fifth Anniversary Volume, 19051980: The Economic Geology Publishing Co., El Paso, Texas, p. 235-269.

Cas, R.A.F., and Wright, J.V., 1987, Volcanic successions: modern and ancient: London, Allen and Unwin, $528 \mathrm{p}$.

Cobbing, E.J., and Pitcher, W.S., 1972, The coastal batholith of central Peru: Journal of the Geological Society of London, v. 128, p. 421-460.

Colman, S.M., and Pierce, K.L., 1981, Weathering rinds on andesitic and basaltic stones as a Quaternary age indicator, western United States: U.S. Geological Survey Professional Paper 1210, $56 \mathrm{p}$.

Condie, K.C., and Swenson, D.H., 1973, Compositional variation in three Cascade stratovolcanoes: Jefferson, Rainier, and Shasta: Bulletin Volcanologique, v. 37, p. $205-230$.

Crandell, D.R., 1987, Deposits of pre-1980 pyroclastic flows and lahars from Mount St. Helens, Washington: U.S. Geological Survey Professional Paper 1444, 91 p.

Crandell, D.R., and Miller, R.D., 1974, Quaternary stratigraphy and extent of glaciation in the Mount Rainier region, Washington: U.S. Geological Survey Professional Paper 847, $59 \mathrm{p}$.

Criswell, C.W., 1987, Chronology and pyroclastic stratigraphy of the May 18, 1980, eruption of Mount St. Helens, Washington: Journal of Geophysical Research, v. 92, p. 10,237-10,266.

Dethier, D.P., 1988, The soil chronosequence along the Cowlitz River, Washington: U.S. Geological Survey Bulletin 1590-F, p. F1-F47.

Evarts, R.C., and Ashley, R.P., 1993a, Geologic map of the Spirit Lake West quadrangle, Skamania and Cowlitz Counties, Washington: U.S. Geological Survey Geologic Quadrangle Map GQ-1681, scale 1:24,000.

- 1993b, Geologic map of the Cowlitz Falls quadrangle, Lewis and Skamania Counties, Washington: U.S. Geological Survey Geologic Quadrangle Map GQ-1682, scale 1:24,000.

Evarts, R.C., Ashley, R.P., and Smith, J.G., 1987, Geology of the Mount St. Helens area: record of discontinuous volcanic and plutonic activity in the Cascade arc of southern Washington: Journal of Geophysical Research, v. 92, p. 10,155-10,169. 
Evarts, R.C., Gray, L.G., Smith, J.G., and Tosdal, R.M., in press, Isotopic and fission-track ages of volcanic and plutonic rocks in the Spirit Lake 15-minute quadrangle and adjacent areas, southwestern Washington: Isochron West.

Fisher, R.V., Glicken, H.X., and Hoblitt, R.P., 1987, May 18, 1980, Mount St. Helens deposits in South Coldwater Creek, Washington: Journal of Geophysical Research, v. 92, p. 10,267-10,283.

Fiske, R.S., Hopson, C.A., and Waters, A.C., 1963, Geology of Mount Rainier National Park, Washington: U.S. Geological Survey Professional Paper 444, 93 p.

Gill, J.B., 1981, Orogenic andesites and plate tectonics: New York, Springer-Verlag, 390 p.

Hammond, P.E., 1979, A tectonic model for evolution of the Cascade Range, in Armentrout, J.M., Cole, M.R., and TerBest, Harry, Jr., eds., Pacific Coast Paleogeography Symposium 3: Cenozoic paleogeography of the western United States: Pacific Section of the Society of Economic Paleontologists and Mineralogists, Los Angeles, Calif., p. 219-237.

- 1980, Reconnaissance geologic map and cross sections of southern Washington Cascade Range, latitude $45^{\circ} 30^{\prime}-47^{\circ} 15^{\prime} \mathrm{N}$, longitude $120^{\circ} 45^{\prime}$ $122^{\circ} 22.5^{\prime} \mathrm{W}$ : Portland, Oreg., Portland State University, Department of Earth Sciences, scale $1: 125,000$.

Hammond, P.E., and Korosec, M.A., 1983, Geochemical analyses, age dates, and flow-volume estimates for Quaternary volcanic rocks, southern Cascade Mountains, Washington: Washington Division of Geology and Earth Resources Open-File Report 8313, $36 \mathrm{p}$.

Hildreth, W., and Fierstein, J., 1985, Mount Adams: eruptive history of an andesite-dacite stratovolcano at the focus of a fundamentally basaltic volcanic field, in Guffanti, M., and Muffler, L.J.P., eds., Proceedings of the Workshop on geothermal resources of the Cascade Range, May 22-23, 1985, Menlo Park, Calif.: U.S. Geological Survey Open-File Report 85521, p. $44-50$.

Hoblitt, R.P., Miller, C.D., and Vallance, J.W., 1981, Origin and stratigraphy of the deposit produced by the May 18 directed blast, in Lipman, P.W., and Mullineaux, D.R., eds., The 1980 eruptions of Mount St. Helens, Washington: U.S. Geological Survey Professional Paper 1250, p. 401-419.

Hollister, V.F., 1979, Porphyry copper-type deposits of the Cascade volcanic arc, Washington: Mineral Science and Engineering, v. 11, p. 22-35.

Hopson, C.A., 1971, Eruptive sequence at Mount St. Helens, Washington [abs.]: Geological Society of America Abstracts with Program, v. 3, no. 2, p. 138.
Irvine, T.N., and Baragar, W.R.A., 1971, A guide to the chemical classification of the common igneous rocks: Canadian Journal of Earth Sciences, v. 8, p. 523548.

Jackson, L.L., Brown, F.W., and Neil, S.T., 1987, Major and minor elements requiring individual determination, classical whole rock analysis, and rapid rock analysis, in Baedecker, P.A., ed., Methods for geochemical analysis: U.S. Geological Survey Bulletin 1770, p. G1-G23.

Le Bas, M.J., Le Maitre, R.W., Streckeisen, A., and Zanettin, B., 1986, A chemical classification of volcanic rocks based on the total alkali-silica diagram: Journal of Petrology, v. 27, p. 745-750.

Lipman, P.W., and Mullineaux, D.R., eds., 1981, The 1980 eruptions of Mount St. Helens, Washington: U.S. Geological Survey Professional Paper 1250, $844 \mathrm{p}$.

Miyashiro. A., 1974, Volcanic rocks series in island arcs and active continental margins: American Journal of Science. v. 274, p. 321-355.

Moen, W.S., 1977, St. Helens and Washougal Mining Districts of the southern Cascades of Washington: Washington Division of Geology and Earth Resources Information Circular No. 60, $71 \mathrm{p}$.

Moore, J.G., and Sisson, T.W., 1981, Deposits and effects of the May 18 pyroclastic surge, in Lipman, P.W., and Mullineaux, D.R., eds., The 1980 eruptions of Mount St. Helens, Washington: U.S. Geological Survey Professional Paper 1250, p. 421438.

Mullineaux, D.R., 1986, Summary of pre-1980 tephrafall deposits erupted from Mount St. Helens, Washington state, USA: Bulletin of Volcanology, v. 48 , p. $17-26$

Mullineaux, D.R., and Crandell, D.R., 1981, The eruptive history of Mount St. Helens, in Lipman, P.W., and Mullineaux, D.R., eds., The 1980 eruptions of Mount St. Helens, Washington: U.S. Geological Survey Professional Paper 1250, p. 3-15.

Mundorff, M.J., 1984, Glaciation in the lower Lewis River basin, southwestern Cascade Range, Washington: Northwest Science, v. 58, p. 269-281.

Shapiro, Leonard, 1975, Rapid analysis of silicate, carbonate, and phosphate rocks-revised edition: U.S. Geological Survey Bulletin 1401, 76 p.

Smith, D.R., and Leeman, W.P., 1987, Petrogenesis of Mount St. Helens dacitic magmas: Journal of Geophysical Research, v. 92, p. 10,313-10,334.

Smith, J.G., in press, Geologic map of upper Eocene to Holocene volcanic and related rocks in the Cascade Range, Washington: U.S. Geological Survey Miscellaneous Investigations Series Map 1-2005, scale 1:500,000.

Steiger, R.H., and Jåger, E., 1977, Subcommission on geochronology: convention on the use of decay constants in geo- and cosmochronology: Earth and Planetary Science Letters, v., 36, p. 359-362. 
Streckeisen, A., 1976, To each plutonic rock its proper name: Earth-Science Reviews, v. 12, p. 1-33.

Swanson, D.A., 1966, Tieton volcano, a middle Miocene eruptive center in the southern Cascade Mountains, Washington: Geological Society of America Bulletin, v. 77 , p. $1293-1314$.

- 1989, Geologic maps of the French Butte and Greenhorn Buttes quadrangles, Washington: U.S. Geological Survey Open-File Report 89-309, scale $1: 24,000$.

Swanson, D.A., Cameron, K.A., Evarts, R.C., Pringle, P.T., and Vance, J.A., 1989, Cenozoic volcanism in the Cascade Range and Columbia Plateau, southern Washington and northernmost Oregon: American Geophysical Union, 28th International Geological Congress Field Trip Guidebook T106, 60 p.

Tabor, R.W., and Crowder, D.F., 1969, On batholiths and volcanoes-Intrusion and eruption of Late Cenozoic magmas in the Glacier Peak area, north Cascades, Washington: U.S. Geological Survey Professional Paper 604, $67 \mathrm{p}$.

Taggart, J.E., Jr., Lindsay, J.R., Scott, B.A., Vivit, D.V., Bartel, A.J., and Stewart, K.C., 1987, Analysis of geological materials by wavelength-dispersive X-ray fluorescence spectrometry, in Baedecker, P.A., ed., Methods for geochemical analysis: U.S. Geological Survey Bulletin 1770, p. E1-E19.
Voight, Barry, Glicken, Harry, Janda, R.J., and Douglass, P.M., 1981, Catastrophic rockslide-avalanche of May 18, in Lipman, P.W., and Mullineaux, D.R., eds., The 1980 eruptions of Mount St. Helens, Washington: U.S. Geological Survey Professional Paper 1250, p. 347-377.

Waitt, R.B., Jr., 1981, Devastating pyroclastic density flow and attendant air fall of May 18-Stratigraphy and sedimentology of deposits, in Lipman, P.W., and Mullineaux, D.R., eds., The 1980 eruptions of Mount St. Helens, Washington: U.S. Geological Survey Professional Paper 1250, p. 439-458.

Waitt, R.B., Jr., and Dzurisin, Daniel, 1981, Proximal airfall deposits from the May 18 eruption-Stratigraphy and field sedimentology, in Lipman, P.W., and Mullineaux, D.R., eds., The 1980 eruptions of Mount St. Helens, Washington: U.S. Geological Survey Professional Paper 1250, p. 601-616.

Walsh, T.J., Korosec, M.A., Phillips, W.M., Logan, R.L., and Schasse, H.W., 1987, Geologic map of Washington-southwest quadrant: Washington Division of Geology and Earth Resources Map GM34 , scale 1:250,000.

Wise, W.S., 1970, Cenozoic volcanism in the Cascade Mountains of southern Washington: Washington Division of Mines and Geology Bulletin 60, $45 \mathrm{p}$. 
Table 1. Summary of fission-track (FT) and isotopic age determinations, Spirit Lake East quadrangle [Source from Evarts and others (in press) except where otherwise noted]

\begin{tabular}{|c|c|c|c|c|c|c|c|c|c|}
\hline \multirow{2}{*}{$\begin{array}{l}\text { Map } \\
\text { No. }\end{array}$} & \multirow{2}{*}{$\begin{array}{l}\text { Field } \\
\text { sample No. }\end{array}$} & \multicolumn{2}{|c|}{ Location } & \multirow{2}{*}{$\begin{array}{l}\text { Map } \\
\text { unit }\end{array}$} & \multirow{2}{*}{$\begin{array}{l}\text { Rock } \\
\text { type }\end{array}$} & \multirow{2}{*}{$\begin{array}{l}\text { Material } \\
\text { dated }\end{array}$} & \multirow[t]{2}{*}{ Method } & \multirow{2}{*}{$\begin{array}{l}\text { Age (Ma) } \\
\pm 1 \sigma \text { error }\end{array}$} & \multirow[t]{2}{*}{ Comments } \\
\hline & & Latitude & Longitude & & & & & & \\
\hline \multirow[t]{3}{*}{1} & \multirow[t]{3}{*}{ S78-D5-E199A } & \multirow[t]{3}{*}{$46^{\circ} 15^{\prime} 24^{\prime \prime}$} & \multirow[t]{3}{*}{$122^{\circ} 03^{\prime} 44^{\prime \prime}$} & \multirow[t]{3}{*}{ Tt } & \multirow{3}{*}{$\begin{array}{l}\text { Vitrophyric } \\
\text { welded tuff }\end{array}$} & Plagioclase & K-Ar & $24.3 \pm 0.9$ & \\
\hline & & & & & & Plagioclase & K-Ar & $23.8 \pm 0.8$ & מ-_ \\
\hline & & & & & & & & $24.0 \pm 0.6$ & Weighted mean age \\
\hline \multirow[t]{3}{*}{2} & \multirow[t]{3}{*}{ S78-D5-E168A } & \multirow[t]{3}{*}{$46^{\circ} 16^{\prime} 06^{\prime \prime}$} & \multirow[t]{3}{*}{$122^{\circ} 02^{\prime} 50^{\prime \prime}$} & \multirow[t]{3}{*}{ Tia } & \multirow{3}{*}{$\begin{array}{l}\text { Pyroxene } \\
\text { andesite }\end{array}$} & Whole rock & $\mathrm{K}-\mathrm{Ar}$ & $8.7 \pm 0.3$ & Probable Ar loss; minimum age \\
\hline & & & & & & Plagioclase & ${ }^{40} \mathrm{Ar} /{ }^{39} \mathrm{Ar}$ & $24.3 \pm 0.3$ & Incremental heating age \\
\hline & & & & & & Plagioclase & ${ }^{40} \mathrm{Ar} /{ }^{39} \mathrm{Ar}$ & $28.6 \pm 1.6$ & Laser incremental heating age \\
\hline \multirow[t]{2}{*}{3} & S78-D5-M88A & $46^{\circ} 15^{\prime} 06^{\prime \prime}$ & $122^{\circ} 02^{\prime} 55^{\prime \prime}$ & Tia & Andesite & Whole rock & $\mathrm{K}-\mathrm{Ar}$ & $9.3 \pm 0.3$ & Probable Ar loss; minimum age \\
\hline & & & & & & Whole rock & ${ }^{40} \mathrm{Ar} /{ }^{39} \mathrm{Ar}$ & $12.9 \pm 0.3$ & $\begin{array}{l}\text { Recombined total fusion age from } \\
\text { discordant incremental heating ex- } \\
\text { periment; minimum age }\end{array}$ \\
\hline 4 & S79-C4-E16 & $46^{\circ} 19^{\prime} 28^{\prime \prime}$ & $122^{\circ} 07^{\prime} 11^{\prime \prime}$ & Tsm & Granodiorite & Zircon & FT & $20.6 \pm 0.8$ & - \\
\hline 5 & S76-C3-N38 & $46^{\circ} 21^{\prime} 13^{\prime \prime}$ & $122^{\circ} 03^{\prime} 40^{\prime \prime}$ & do & -.--do-n & Zircon & FT & $21.8 \pm 0.7$ & \\
\hline 6 & S79-C3-R127 & $46^{\circ} 22^{\prime} 17^{\prime \prime}$ & $122^{\circ} 03^{\prime} 12^{\prime \prime}$ & Tsgr & Granite & Zircon & FT & $21.4 \pm 0.7$ & \\
\hline 7 & S78-C5-E123A & $46^{\circ} 17^{\prime} 23^{\prime \prime}$ & $122^{\circ} 05^{\prime} 29^{\prime \prime}$ & Thp & $\begin{array}{l}\text { Hornblende } \\
\text { porphyry }\end{array}$ & Hornblende & $\mathrm{K}-\mathrm{Ar}$ & $19.9 \pm 0.7$ & $\begin{array}{l}\text { Cuts contact-metamorphic aureole of } \\
\text { Spirit Lake pluton, but not recrystal- } \\
\text { lized }\end{array}$ \\
\hline \multirow[t]{2}{*}{8} & S84-C3-R03 & $46^{\circ} 21^{\prime} 21^{\prime \prime}$ & $122^{\circ} 05^{\circ} 00^{\prime \prime}$ & $\mathrm{Tq}$ & $\begin{array}{c}\text { Altered } \\
\text { quartz }\end{array}$ & Zircon & $\mathrm{U}-\mathrm{Pb}$ & $19.1 \pm 0.1$ & Crystallization age \\
\hline & & & & & & Zircon & FT & $18.8 \pm 0.6$ & Crystallization age \\
\hline 9 & MDH7-684/687 & $46^{\circ} 21^{\prime} 25^{\prime \prime}$ & $122^{\circ} 04^{\prime} 52^{\prime \prime}$ & Tsm & $\begin{array}{l}\text { Altered } \\
\text { granodiorite }\end{array}$ & Sericite & $\mathrm{K}-\mathrm{Ar}$ & $16.9 \pm 0.5$ & $\begin{array}{l}\text { Secondary sericite from phyllic zone } \\
\text { of Earl porphyry copper deposit }\end{array}$ \\
\hline 10 & $\mathrm{MDH} 6-408 / 410$ & $46^{\circ} 21^{\prime} 20^{\prime \prime}$ & $122^{\circ} 04^{\prime} 52^{\prime \prime}$ & do & -ndo-- & Biotite & $\mathrm{K}-\mathrm{Ar}$ & $17.3 \pm 0.5$ & $\begin{array}{l}\text { Secondary biotite from potassic zone } \\
\text { of Earl porphyry copper deposit }\end{array}$ \\
\hline 11 & Earl & $46^{\circ} 21^{\prime}$ & $122^{\circ} 05^{\prime}$ & do & - do & Biotite & $\mathrm{K}-\mathrm{Ar}$ & $16.6 \pm 0.6$ & $\begin{array}{l}\text { Secondary biotite from potassic zone } \\
\text { of Earl porphyry-copper deposit. Pub- } \\
\text { lished age (Armstrong and others. } \\
\text { 1976) recalculated using currently } \\
\text { accepted physical constants (Steiger } \\
\text { and Jäger, 1977) }\end{array}$ \\
\hline
\end{tabular}


Table 2. Chemical analyses and modes of volcanic and hypabyssal intrusive rocks, Spirit Lake East quadrangle

(Oxides in weight percent. For modal analyses, secondary minerals counted as primary mineral replaced; tr, trace; maf, unidentified mafic silicates; bi, biotite; px, pyroxene. Rock types assigned in accordance with International Union of Geological Sciences (1.U.G.S.) scheme of Streckeisen (1976) for plutonic rocks and I.U.G.S. system of Le Bas and others (1986) applied to recalculated analyses for volcanic rocks. Methods: RR, singlesolution rapid rock analysis as described by Shapiro (1975); analysts, J. Gillison, and $H$. Smith. XRF, X-ray fluorescence analysis using methods described by Taggart and others (1987), analysts: J. Baker, A.J. Bartel, D. Fey, D. Siems, K. Stewart, J.E. Taggart, and J.S. Wahlberg; FeO, H2O, and $\mathrm{CO}_{2}$ determined by methods detailed in Jackson and others (1987); analysts, E. Engelman, L. Espos, P. Klock, S. Neil, and H. Neiman. Texure: first term describes overall rock texture; second term (where appropriate) describes groundmass.]

\begin{tabular}{|c|c|c|c|c|c|c|c|c|c|}
\hline Map No. & 1 & 2 & 3 & 4 & 5 & 6 & 7 & 8 & 9 \\
\hline $\begin{array}{l}\text { Field sample } \\
\text { number }\end{array}$ & 2E65A & 2R27 & $8 \mathrm{E} 117 \mathrm{~B}$ & $5 E 66 \mathrm{~A}$ & $8 \mathrm{M} 74$ & $8 \mathrm{E} 167 \mathrm{~A}$ & 2E07 & 2E14 & $9 \mathrm{C} 35 \mathrm{~B}$ \\
\hline $\begin{array}{l}\text { Latitude } \\
\text { Longitude }\end{array}$ & $\begin{array}{l}46^{\circ} 15^{\prime} 52^{\prime \prime} \\
122^{\circ} 05^{\prime} 30^{\prime \prime}\end{array}$ & $\begin{array}{c}46^{\circ} 16^{\prime} 39^{\prime \prime} \\
122^{\circ} 022^{\prime \prime} 27^{\prime \prime}\end{array}$ & $\begin{array}{l}46^{\circ} 17^{\prime} 09^{\prime \prime} \\
122^{\circ} 04^{\prime} 50^{\prime \prime}\end{array}$ & $\begin{array}{c}46^{\circ} 16^{\prime} 16^{\prime \prime} \\
122^{\circ} 022^{\prime \prime} 26^{\prime \prime}\end{array}$ & $\begin{array}{l}46^{\circ} 15^{\prime} 27^{\prime \prime} \\
122^{\circ} 05^{\prime} 22^{\prime \prime}\end{array}$ & $\begin{array}{l}46^{\circ} 16^{\prime} 06^{\prime \prime} \\
122^{\circ} 03^{\prime} 55^{\prime \prime}\end{array}$ & $\begin{array}{c}46^{\circ} 17^{\prime} 40^{\prime \prime} \\
122^{\circ} 02^{\prime} 06^{\prime \prime}\end{array}$ & $\begin{array}{l}46^{\circ} 15^{\prime} 13^{\prime \prime} \\
122^{\circ} 011^{\prime} 12^{\prime \prime}\end{array}$ & $\begin{array}{c}46^{\circ} 17^{\prime} 48^{\prime \prime} \\
122^{\circ} 05^{\prime} 15^{\prime \prime}\end{array}$ \\
\hline Map unit & $\mathrm{Tb}$ & $\mathrm{Tb}$ & Tdi & Tdi & Tsc & Tia & $\mathrm{Ta}$ & $\mathrm{Ta}$ & Tdi \\
\hline Rock type & $\begin{array}{c}\text { Basaltic } \\
\text { andesite }\end{array}$ & Basalt & Diorite & Diorite & Diorite & $\begin{array}{c}\text { Basaltic } \\
\text { andesite }\end{array}$ & $\begin{array}{c}\text { Basaltic } \\
\text { andesite }\end{array}$ & $\begin{array}{c}\text { Basaltic } \\
\text { andesite }\end{array}$ & Diorite \\
\hline Method & $\mathrm{XRF}$ & $\mathrm{XRF}$ & $\mathrm{RR}$ & $\mathrm{XRF}$ & $\mathrm{RR}$ & $\mathrm{XRF}$ & $\mathrm{XRF}$ & $\mathrm{XRF}$ & $\mathrm{RR}$ \\
\hline $\begin{array}{l}\mathrm{SiO}_{2} \\
\mathrm{TiO}_{2} \\
\mathrm{Al}_{2} \mathrm{O}_{3} \\
\mathrm{Fe}_{2} \mathrm{O}_{3} \\
\mathrm{FeO} \\
\mathrm{MnO} \\
\mathrm{MgO} \\
\mathrm{CaO} \\
\mathrm{Na}_{2} \mathrm{O} \\
\mathrm{K}_{2} \mathrm{O} \\
\mathrm{P}_{2} \mathrm{O}_{5} \\
\mathrm{H}_{2} \mathrm{O}^{+}\end{array}$ & $\begin{array}{c}50.4 \\
1.33 \\
17.5 \\
4.77 \\
4.33 \\
0.15 \\
4.98 \\
10.1 \\
2.53 \\
0.11 \\
0.17 \\
1.32\end{array}$ & $\begin{array}{c}50.6 \\
1.15 \\
18.4 \\
3.04 \\
5.71 \\
0.15 \\
5.12 \\
10.2 \\
2.71 \\
0.21 \\
0.19 \\
1.24\end{array}$ & $\begin{array}{c}51.9 \\
1.1 \\
16.9 \\
2.6 \\
5.6 \\
0.14 \\
5.5 \\
8.6 \\
3.1 \\
0.55 \\
0.19 \\
1.4\end{array}$ & $\begin{array}{c}52.1 \\
1.38 \\
18.5 \\
4.09 \\
4.88 \\
0.15 \\
3.97 \\
9.12 \\
3.08 \\
1.12 \\
0.15 \\
0.99\end{array}$ & $\begin{array}{c}52.4 \\
1.2 \\
17.5 \\
4.3 \\
4.0 \\
0.16 \\
4.0 \\
8.4 \\
2.9 \\
0.80 \\
0.22 \\
1.1\end{array}$ & $\begin{array}{c}52.6 \\
1.53 \\
17.4 \\
2.93 \\
6.37 \\
0.17 \\
4.20 \\
9.40 \\
3.04 \\
0.32 \\
0.25 \\
1.04\end{array}$ & $\begin{array}{c}53.1 \\
0.92 \\
17.5 \\
2.43 \\
4.56 \\
0.14 \\
5.28 \\
8.86 \\
3.08 \\
0.76 \\
0.16 \\
1.23\end{array}$ & $\begin{array}{c}53.4 \\
1.21 \\
16.8 \\
3.00 \\
5.41 \\
0.18 \\
5.01 \\
8.73 \\
2.92 \\
0.42 \\
0.21 \\
1.32\end{array}$ & $\begin{array}{c}53.8 \\
1.0 \\
18.1 \\
4.1 \\
4.2 \\
0.15 \\
4.4 \\
8.9 \\
3.1 \\
0.54 \\
0.18 \\
1.2\end{array}$ \\
\hline $\mathrm{H}_{2} \mathrm{O}^{-}$ & 1.07 & 1.09 & 0.67 & 0.57 & 2.2 & 0.55 & 0.95 & 1.46 & 0.50 \\
\hline $\mathrm{CO}_{2}$ & 0.09 & 0.05 & 0.82 & 0.13 & 0.78 & 0.11 & 0.07 & 0.05 & 0.02 \\
\hline Total & $\overline{98.85}$ & $\overline{99.86}$ & $\overline{99.07}$ & $1 \overline{00.23}$ & $\overline{99.96}$ & $\overline{99.91}$ & $\overline{99.04}$ & $1 \overline{00.12}$ & $1 \overline{00.19}$ \\
\hline
\end{tabular}

Analyses recalculated volatile-free and normalized to 100 percent

\begin{tabular}{|c|c|c|c|c|c|c|c|c|c|}
\hline $\begin{array}{l}\mathrm{SiO}_{2} \\
\mathrm{TiO}_{2} \\
\mathrm{Al}_{2} \mathrm{O}_{3} \\
\mathrm{Fe}_{2} \mathrm{O}_{3} \\
\mathrm{FeO} \\
\mathrm{MnO} \\
\mathrm{MgO} \\
\mathrm{CaO} \\
\mathrm{Na}_{2} \mathrm{O} \\
\mathrm{K}_{2} \mathrm{O} \\
\mathrm{P}_{2} \mathrm{O}_{5}\end{array}$ & $\begin{array}{r}52.30 \\
1.38 \\
18.16 \\
4.95 \\
4.49 \\
0.16 \\
5.17 \\
10.48 \\
2.63 \\
0.11 \\
0.18\end{array}$ & $\begin{array}{r}51.91 \\
1.18 \\
18.88 \\
3.12 \\
5.86 \\
0.15 \\
5.25 \\
10.46 \\
2.78 \\
0.22 \\
0.19\end{array}$ & $\begin{array}{r}53.96 \\
1.14 \\
17.57 \\
2.70 \\
5.82 \\
0.15 \\
5.72 \\
8.94 \\
3.22 \\
0.57 \\
0.20\end{array}$ & $\begin{array}{r}52.87 \\
1.40 \\
18.77 \\
4.15 \\
4.95 \\
0.15 \\
4.03 \\
9.26 \\
3.13 \\
1.14 \\
0.15\end{array}$ & $\begin{array}{r}54.65 \\
1.25 \\
18.25 \\
4.48 \\
4.17 \\
0.17 \\
4.17 \\
8.76 \\
3.02 \\
0.83 \\
0.23\end{array}$ & $\begin{array}{c}53.56 \\
1.56 \\
17.72 \\
2.98 \\
6.49 \\
0.17 \\
4.28 \\
9.57 \\
3.10 \\
0.33 \\
0.25\end{array}$ & $\begin{array}{r}54.86 \\
0.95 \\
18.08 \\
2.51 \\
4.71 \\
0.14 \\
5.46 \\
9.15 \\
3.18 \\
0.79 \\
0.17\end{array}$ & $\begin{array}{r}54.89 \\
1.24 \\
17.27 \\
3.08 \\
5.56 \\
0.19 \\
5.15 \\
8.97 \\
3.00 \\
0.43 \\
0.22\end{array}$ & $\begin{array}{r}54.64 \\
1.02 \\
18.38 \\
4.16 \\
4.27 \\
0.15 \\
4.47 \\
9.04 \\
3.15 \\
0.55 \\
0.18\end{array}$ \\
\hline
\end{tabular}

Modes

\begin{tabular}{|c|c|c|c|c|c|c|c|c|c|}
\hline $\begin{array}{l}\text { Plagioclase } \\
\text { Clinopyroxene } \\
\text { Orthopyroxene } \\
\text { Olivine } \\
\text { Fe-Ti oxide } \\
\text { Hornblende } \\
\text { Quartz } \\
\text { K-feldspar } \\
\text { Other } \\
\text { Groundmass } \\
\text { No. of points } \\
\text { counted } \\
\text { Texture }\end{array}$ & \begin{tabular}{c}
24.4 \\
\hdashline-- \\
\hdashline 2.5 \\
\hdashline-- \\
-- \\
$-\overline{-}$ \\
$\overline{73.1}$ \\
802 \\
porphyritic/ \\
intergranular
\end{tabular} & \begin{tabular}{c}
26.2 \\
1.1 \\
2.9 \\
3.0 \\
\hdashline-- \\
\hdashline-- \\
.-- \\
66.8 \\
729
\end{tabular} & \begin{tabular}{c}
55.8 \\
15.2 \\
7.0 \\
maf 11.1 \\
1.8 \\
\hdashline 5.0 \\
4.1 \\
705 \\
seriate/ \\
hypidiomorphic
\end{tabular} & \begin{tabular}{c}
62.9 \\
11.8 \\
5.9 \\
2.3 \\
1.8 \\
0.9 \\
9.3 \\
4.6 \\
bi 0.5 \\
\hdashline 760 \\
seriate/ \\
hypidiomorphic
\end{tabular} & \begin{tabular}{c}
60.7 \\
4.7 \\
10.8 \\
\hdashline 1.4 \\
6.5 \\
.-- \\
\hdashline 15.9 \\
779 \\
seriate/ \\
intergranular
\end{tabular} & 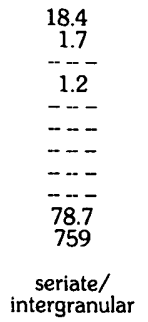 & \begin{tabular}{c}
69.0 \\
13.6 \\
7.2 \\
5.0 \\
1.2 \\
\hdashline- \\
- \\
4.0 \\
814 \\
seriate/ \\
intergranular
\end{tabular} & \begin{tabular}{c}
23.8 \\
5.2 \\
\hdashline 1.1 \\
\hdashline-- \\
\hdashline.-- \\
69.9 \\
794 \\
porphyritic/ \\
intersertal
\end{tabular} & $\begin{array}{c}62.3 \\
11.5 \\
16.9 \\
0.4 \\
1.8 \\
--- \\
--- \\
7.1 \\
549 \\
\text { intergranular }\end{array}$ \\
\hline
\end{tabular}


Table 2. Chemical analyses and modes of volcanic and hypabyssal intrusive rocks, Spirit Lake East quadrangle-Continued

\begin{tabular}{|c|c|c|c|c|c|c|c|c|c|}
\hline Map No. & 10 & 11 & 12 & 13 & 14 & 15 & 16 & 17 & 18 \\
\hline $\begin{array}{l}\text { Field sample } \\
\text { number }\end{array}$ & $8 \mathrm{R} 82$ & 2E09 & $8 W 56$ & $5 \mathrm{E} 21 \mathrm{~A}$ & $3 E 52$ & $2 \mathrm{E} 125 \mathrm{~B}$ & 7R22 & $3 \mathrm{E} 81 \mathrm{~B}$ & 2E53 \\
\hline $\begin{array}{l}\text { Latitude } \\
\text { Longitude }\end{array}$ & $\begin{array}{l}46^{\circ} 15^{\circ} 36^{\prime \prime} \\
122^{\circ} 00^{\circ} 00^{\prime \prime}\end{array}$ & $\begin{array}{c}46^{\circ} 16^{\prime} 19^{\prime \prime} \\
122^{\circ} 01^{\prime} 46^{\prime \prime}\end{array}$ & $\begin{array}{c}46^{\circ} 15^{\prime} 24^{\prime \prime} \\
122^{\circ} 04^{\prime} 21^{\prime \prime}\end{array}$ & $\begin{array}{l}46^{\circ} 211^{\prime 3} 4^{\prime \prime} \\
122^{\circ} 01^{\prime} 33^{\prime \prime}\end{array}$ & $\begin{array}{c}46^{\circ} 16^{\prime} 15^{\prime \prime} \\
122^{\circ} 04^{\prime} 20^{\prime \prime}\end{array}$ & $\begin{array}{c}46^{\circ} 17^{\circ} 09^{\prime \prime} \\
122^{\circ} 06^{\circ} 40^{\prime \prime}\end{array}$ & $\begin{array}{c}46^{\circ} 211^{\prime} 40^{\prime \prime} \\
122^{\circ} 00^{\prime} 15^{\prime \prime}\end{array}$ & $\begin{array}{l}46^{\circ} 15^{\prime} 33^{\prime \prime} \\
122^{\circ} 02^{\prime} 35^{\prime \prime}\end{array}$ & $\begin{array}{l}46^{\circ} 15^{\prime} 51^{\prime \prime} \\
122^{\circ} 05^{\prime} 17^{\prime \prime}\end{array}$ \\
\hline Map unit & $\mathrm{Ta}$ & $\mathrm{Ta}$ & $\mathrm{Ta}$ & Tdi & Tia & Tqd & $\mathrm{Ta}$ & Ta & $\mathrm{Ta}$ \\
\hline Rock type & $\begin{array}{l}\text { Basaltic } \\
\text { andesite }\end{array}$ & $\begin{array}{l}\text { Basaltic } \\
\text { andesite }\end{array}$ & $\begin{array}{l}\text { Basaltic } \\
\text { andesite }\end{array}$ & Diorite & Andesite & $\begin{array}{l}\text { Quartz } \\
\text { diorite }\end{array}$ & $\begin{array}{l}\text { Basaltic } \\
\text { andesite }\end{array}$ & Andesite & Andesite \\
\hline Method & $\mathrm{RR}$ & $\mathrm{XRF}$ & $\mathrm{RR}$ & $\mathrm{XRF}$ & $\mathrm{XRF}$ & XRF & $\mathrm{RR}$ & $\mathrm{XRF}$ & $\mathrm{XRF}$ \\
\hline $\begin{array}{l}\mathrm{SiO}_{2} \\
\mathrm{TiO}_{2} \\
\mathrm{Al}_{2} \mathrm{O}_{3} \\
\mathrm{Fe}_{2} \mathrm{O}_{3} \\
\mathrm{FeO} \\
\mathrm{MnO} \\
\mathrm{MgO} \\
\mathrm{COO} \\
\mathrm{Na}_{2} \mathrm{O} \\
\mathrm{K}_{2} \mathrm{O} \\
\mathrm{P}_{2} \mathrm{O}_{5} \\
\mathrm{H}_{2} \mathrm{O}+ \\
\mathrm{H}_{2} \mathrm{O} \\
\mathrm{CO}_{2}\end{array}$ & $\begin{array}{c}53.9 \\
1.2 \\
16.8 \\
3.3 \\
4.9 \\
0.14 \\
4.8 \\
8.4 \\
3.1 \\
0.75 \\
0.24 \\
0.70 \\
1.4 \\
0.02\end{array}$ & $\begin{array}{c}54.7 \\
1.45 \\
16.2 \\
3.61 \\
5.02 \\
0.12 \\
3.74 \\
8.07 \\
2.74 \\
1.30 \\
0.26 \\
1.22 \\
1.62 \\
0.04\end{array}$ & $\begin{array}{c}54.7 \\
1.2 \\
18.0 \\
4.4 \\
4.0 \\
0.14 \\
3.1 \\
7.4 \\
3.7 \\
0.82 \\
0.29 \\
0.40 \\
1.3 \\
0.28\end{array}$ & $\begin{array}{c}54.8 \\
1.19 \\
17.0 \\
2.96 \\
5.37 \\
0.14 \\
4.29 \\
8.70 \\
2.81 \\
0.93 \\
0.18 \\
1.24 \\
0.33 \\
0.08\end{array}$ & $\begin{array}{c}55.4 \\
1.95 \\
14.2 \\
4.56 \\
6.25 \\
0.19 \\
3.09 \\
7.02 \\
3.09 \\
0.34 \\
0.37 \\
2.32 \\
0.75 \\
0.02\end{array}$ & $\begin{array}{c}55.7 \\
1.06 \\
17.3 \\
2.59 \\
4.85 \\
0.12 \\
3.54 \\
7.68 \\
2.95 \\
1.10 \\
0.17 \\
1.54 \\
0.75 \\
0.46\end{array}$ & $\begin{array}{c}55.7 \\
0.83 \\
16.4 \\
3.6 \\
4.4 \\
0.13 \\
5.1 \\
8.5 \\
3.1 \\
0.80 \\
0.25 \\
0.97 \\
0.92 \\
0.14\end{array}$ & $\begin{array}{c}55.8 \\
1.14 \\
17.5 \\
1.67 \\
5.96 \\
0.14 \\
3.78 \\
7.98 \\
2.84 \\
0.49 \\
0.20 \\
1.73 \\
0.60 \\
0.07\end{array}$ & $\begin{array}{c}55.9 \\
1.04 \\
17.7 \\
3.54 \\
4.08 \\
0.13 \\
3.82 \\
7.29 \\
3.55 \\
0.62 \\
0.18 \\
0.79 \\
0.98 \\
0.18\end{array}$ \\
\hline Total & $\overline{99.65}$ & $1 \overline{00.09}$ & $\overline{99.73}$ & $1 \overline{00.02}$ & $\overline{99.55}$ & $\overline{99.81}$ & $1 \overline{00.84}$ & $\overline{99.91}$ & $\overline{99.80}$ \\
\hline
\end{tabular}

Analyses recalculated volatile-free and normalized to 100 percent

\begin{tabular}{|c|c|c|c|c|c|c|c|c|c|}
\hline $\begin{array}{l}\mathrm{SiO}_{2} \\
\mathrm{TiO}_{2} \\
\mathrm{Al}_{2} \mathrm{O}_{3} \\
\mathrm{Fe}_{2} \mathrm{O}_{3} \\
\mathrm{FeO} \\
\mathrm{MnO} \\
\mathrm{MgO} \\
\mathrm{CaO} \\
\mathrm{Na}_{2} \mathrm{O} \\
\mathrm{K}_{2} \mathrm{O} \\
\mathrm{P}_{2} \mathrm{O}_{5}\end{array}$ & $\begin{array}{r}55.27 \\
1.23 \\
17.23 \\
3.38 \\
5.02 \\
0.14 \\
4.92 \\
8.61 \\
3.18 \\
0.77 \\
0.25\end{array}$ & $\begin{array}{r}56.27 \\
1.49 \\
16.66 \\
3.71 \\
5.16 \\
0.12 \\
3.85 \\
8.30 \\
2.82 \\
1.34 \\
0.27\end{array}$ & $\begin{array}{r}55.96 \\
1.23 \\
18.41 \\
4.50 \\
4.09 \\
0.14 \\
3.17 \\
7.57 \\
3.79 \\
0.84 \\
0.30\end{array}$ & $\begin{array}{r}55.71 \\
1.21 \\
17.28 \\
3.01 \\
5.46 \\
0.14 \\
4.36 \\
8.84 \\
2.86 \\
0.95 \\
0.18\end{array}$ & $\begin{array}{r}57.43 \\
2.02 \\
14.72 \\
4.73 \\
6.48 \\
0.20 \\
3.20 \\
7.28 \\
3.20 \\
0.35 \\
0.38\end{array}$ & $\begin{array}{r}57.39 \\
1.09 \\
17.82 \\
2.67 \\
5.00 \\
0.12 \\
3.65 \\
7.91 \\
3.04 \\
1.13 \\
0.18\end{array}$ & $\begin{array}{r}56.37 \\
0.84 \\
16.60 \\
3.64 \\
4.45 \\
0.13 \\
5.16 \\
8.60 \\
3.14 \\
0.81 \\
0.25\end{array}$ & $\begin{array}{r}57.23 \\
1.17 \\
17.95 \\
1.71 \\
6.11 \\
0.14 \\
3.88 \\
8.18 \\
2.91 \\
0.50 \\
0.21\end{array}$ & $\begin{array}{r}57.13 \\
1.06 \\
18.09 \\
3.62 \\
4.17 \\
0.13 \\
3.90 \\
7.45 \\
3.63 \\
0.63 \\
0.18\end{array}$ \\
\hline
\end{tabular}

Modes

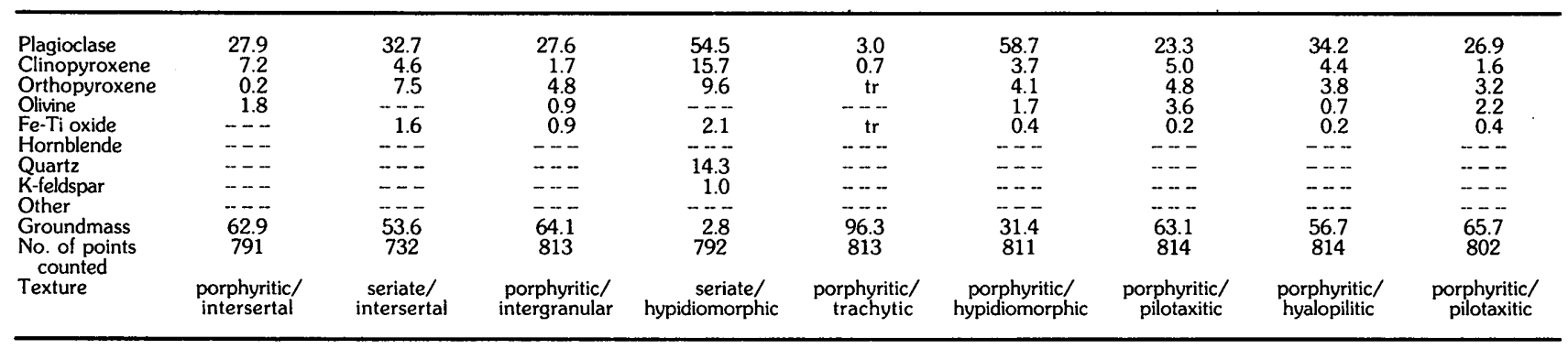


Table 2. Chemical analyses and modes of volcanic and hypabyssal intrusive rocks, Spirit Lake East quadrangle-Continued

\begin{tabular}{|c|c|c|c|c|c|c|c|c|c|}
\hline Map No. & 19 & 20 & 21 & 22 & 23 & 24 & 25 & 26 & 27 \\
\hline $\begin{array}{l}\text { Field sample } \\
\text { number }\end{array}$ & $8 \mathrm{E} 181$ & $6 \mathrm{E} 22$ & 2E63 & $2 \mathrm{E} 70$ & $3 \mathrm{E} 53 \mathrm{C}$ & $8 M 75 B$ & $3 E 72 A$ & $8 M 88 A$ & $2 \mathrm{E} 31$ \\
\hline $\begin{array}{l}\text { Latitude } \\
\text { Longitude }\end{array}$ & $\begin{array}{c}46^{\circ} 16^{\prime} 16^{\prime \prime} \\
122^{\circ} 06^{\prime} 26^{\prime \prime}\end{array}$ & $\begin{array}{l}46^{\circ} 1550^{\prime \prime} \\
122^{\circ} 06^{\circ} 49^{\prime \prime}\end{array}$ & $\begin{array}{l}46^{\circ} 15^{\prime} 11^{\prime \prime} \\
122^{\circ} 06^{\circ} 05^{\prime \prime}\end{array}$ & $\begin{array}{l}46^{\circ} 15^{\circ} 40^{\prime \prime} \\
122^{\circ} 04^{\prime} 44^{\prime \prime}\end{array}$ & $\begin{array}{l}46^{\circ} 15^{\prime} 57^{\prime \prime} \\
122^{\circ} 04^{\prime} 17^{\prime \prime}\end{array}$ & $\begin{array}{c}46^{\circ} 16^{\circ} 26^{\prime \prime} \\
122^{\circ} 04^{\prime} 04^{\prime \prime}\end{array}$ & $\begin{array}{l}46^{\circ} 15^{\prime} 55^{\prime \prime} \\
122^{\circ} 03^{\prime} 43^{\prime \prime}\end{array}$ & $\begin{array}{c}46^{\circ} 15^{\prime} 06^{\prime \prime} \\
122^{\circ} 02^{\prime} 55^{\prime \prime}\end{array}$ & $\begin{array}{c}46^{\circ} 16^{\prime} 28^{\prime \prime} \\
122^{\circ} 03^{\prime} 40^{\prime \prime}\end{array}$ \\
\hline Map unit & $\mathrm{Ta}$ & $\mathrm{Ta}$ & Tia & Tia & $\mathrm{Ta}$ & $\mathrm{Ta}$ & Tia & Tia & Tqd \\
\hline Rock type & Andesite & Andesite & Andesite & Andesite & Andesite & Andesite & Andesite & Andesite & $\begin{array}{r}\text { Quartz } \\
\text { diorite }\end{array}$ \\
\hline Method & $\mathrm{RR}$ & XRF & $\mathrm{XRF}$ & $\mathrm{XRF}$ & XRF & XRF & XRF & $\mathrm{RR}$ & $\mathrm{XRF}$ \\
\hline $\begin{array}{l}\mathrm{SiO}_{2} \\
\mathrm{TiO}_{2} \\
\mathrm{Al}_{2} \mathrm{O}_{3} \\
\mathrm{Fe}_{2} \mathrm{O}_{3} \\
\mathrm{FeO} \\
\mathrm{MnO} \\
\mathrm{MgO} \\
\mathrm{CaO} \\
\mathrm{Na}_{2} \mathrm{O} \\
\mathrm{K}_{2} \mathrm{O} \\
\mathrm{P}_{2} \mathrm{O}_{5} \\
\mathrm{H}_{2} \mathrm{O}+ \\
\mathrm{H}_{2} \mathrm{O} \\
\mathrm{CO}_{2}\end{array}$ & $\begin{array}{c}56.5 \\
1.8 \\
15.1 \\
5.0 \\
5.3 \\
0.16 \\
3.0 \\
6.2 \\
3.7 \\
0.69 \\
0.31 \\
0.80 \\
1.1 \\
0.35\end{array}$ & $\begin{array}{c}56.4 \\
1.88 \\
14.8 \\
3.45 \\
6.71 \\
0.18 \\
2.93 \\
7.29 \\
3.25 \\
0.38 \\
0.28 \\
1.86 \\
0.74 \\
0.14\end{array}$ & $\begin{array}{c}56.7 \\
1.42 \\
16.4 \\
2.78 \\
5.44 \\
0.14 \\
2.84 \\
7.17 \\
3.86 \\
0.41 \\
0.22 \\
1.56 \\
0.58 \\
0.18\end{array}$ & $\begin{array}{c}56.7 \\
1.87 \\
14.8 \\
3.23 \\
6.64 \\
0.17 \\
2.90 \\
6.57 \\
3.72 \\
0.52 \\
0.33 \\
1.75 \\
0.57 \\
0.19\end{array}$ & $\begin{array}{c}56.8 \\
1.88 \\
14.8 \\
3.37 \\
6.24 \\
0.17 \\
2.70 \\
6.61 \\
3.55 \\
0.56 \\
0.28 \\
2.05 \\
0.73 \\
0.12\end{array}$ & $\begin{array}{c}57.3 \\
1.46 \\
16.4 \\
3.22 \\
4.98 \\
0.17 \\
2.81 \\
6.61 \\
3.72 \\
0.99 \\
0.37 \\
0.79 \\
0.83 \\
0.35\end{array}$ & $\begin{array}{c}57.5 \\
1.62 \\
14.6 \\
2.88 \\
6.16 \\
0.17 \\
2.26 \\
5.73 \\
3.98 \\
0.82 \\
0.43 \\
2.17 \\
1.06 \\
0.05\end{array}$ & $\begin{array}{c}57.6 \\
1.4 \\
15.8 \\
3.2 \\
5.6 \\
0.15 \\
2.1 \\
5.9 \\
4.0 \\
1.1 \\
0.36 \\
1.3 \\
0.81 \\
0.02\end{array}$ & $\begin{array}{c}57.9 \\
1.21 \\
16.7 \\
4.03 \\
3.74 \\
0.12 \\
3.12 \\
6.65 \\
4.06 \\
0.82 \\
0.23 \\
0.77 \\
0.33 \\
<0.02\end{array}$ \\
\hline Total & $\overline{99.91}$ & $1 \overline{00.29}$ & $\overline{99.70}$ & $\overline{99.96}$ & $\overline{99.86}$ & $1 \overline{00.00}$ & $\overline{99.43}$ & $\overline{99.34}$ & $\overline{99.68}$ \\
\hline
\end{tabular}

Analyses recalculated volatile-free and normalized to 100 percent

\begin{tabular}{|c|c|c|c|c|c|c|c|c|c|}
\hline $\begin{array}{l}\mathrm{SiO}_{2} \\
\mathrm{TiO}_{2} \\
\mathrm{Al}_{2} \mathrm{O}_{3} \\
\mathrm{Fe}_{2} \mathrm{O}_{3} \\
\mathrm{FeO} \\
\mathrm{MnO} \\
\mathrm{MgO} \\
\mathrm{CaO} \\
\mathrm{Na}_{2} \mathrm{O} \\
\mathrm{K}_{2} \mathrm{O} \\
\mathrm{P}_{2} \mathrm{O}_{5}\end{array}$ & $\begin{array}{r}57.75 \\
1.84 \\
15.46 \\
5.12 \\
5.43 \\
0.16 \\
3.07 \\
6.35 \\
3.79 \\
0.71 \\
0.32\end{array}$ & $\begin{array}{r}57.82 \\
1.93 \\
15.17 \\
3.54 \\
6.88 \\
0.18 \\
3.00 \\
7.47 \\
3.33 \\
0.39 \\
0.29\end{array}$ & $\begin{array}{r}58.23 \\
1.46 \\
16.84 \\
2.85 \\
5.59 \\
0.14 \\
2.92 \\
7.36 \\
3.96 \\
0.42 \\
0.23\end{array}$ & $\begin{array}{r}58.18 \\
1.92 \\
15.19 \\
3.31 \\
6.81 \\
0.17 \\
2.98 \\
6.74 \\
3.82 \\
0.53 \\
0.34\end{array}$ & $\begin{array}{r}58.58 \\
1.94 \\
15.26 \\
3.48 \\
6.44 \\
0.18 \\
2.78 \\
6.82 \\
3.66 \\
0.58 \\
0.29\end{array}$ & $\begin{array}{r}58.45 \\
1.49 \\
16.73 \\
3.28 \\
5.08 \\
0.17 \\
2.87 \\
6.74 \\
3.79 \\
1.01 \\
0.38\end{array}$ & $\begin{array}{r}59.80 \\
1.68 \\
15.18 \\
3.00 \\
6.41 \\
0.18 \\
2.35 \\
5.96 \\
4.14 \\
0.85 \\
0.45\end{array}$ & $\begin{array}{r}59.25 \\
1.44 \\
16.25 \\
3.29 \\
5.76 \\
0.15 \\
2.16 \\
6.07 \\
4.11 \\
1.13 \\
0.37\end{array}$ & $\begin{array}{r}58.73 \\
1.23 \\
16.94 \\
4.09 \\
3.79 \\
0.12 \\
3.16 \\
6.75 \\
4.12 \\
0.83 \\
0.23\end{array}$ \\
\hline \multicolumn{10}{|c|}{ Modes } \\
\hline Plagioclase & 0.6 & 0.3 & 9.5 & 0.1 & 0.1 & 17.4 & 0.2 & 4.7 & 66.2 \\
\hline Clinopyroxene & 0.1 & $\ldots-$ & 0.9 & --- &.-- & 0.8 & tr & 0.5 & -..... \\
\hline Orthopyroxene & $\ldots \ldots$ & $\cdots$ & $\cdots$ & $-\cdots$ & $-\cdots$ & 3.6 & $\mathrm{tr}$ & $\cdots$ & px 20.1 \\
\hline Olivine & --- & $-\cdots$ & 0.3 & -... &.-- & 0.2 & $\ldots$ & 0.2 & 0.4 \\
\hline $\mathrm{Fe}$-Ti oxide & tr & 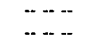 & 0.3 & $\cdots$ & $\cdots$ & 0.6 & tr & $\cdots$ & 3.1 \\
\hline $\begin{array}{l}\text { Hornblende } \\
\text { Quartz }\end{array}$ & $\ldots$ & -...- & -... & -... & $\ldots$ & $-\cdots$ & ... & $\cdots \cdots$ & 72 \\
\hline K-feldspar & $-\ldots$ & $-\ldots$ & $\ldots .$. & $\ldots$ & $\ldots .$. & $\ldots$ & ..... & $\ldots$ & 1.4 \\
\hline Other & $\cdots$ & $\ldots . .-$ & ..... & $\ldots--$ & $-\cdots$ & ---- & -... & $-\cdots$ & bi 1.6 \\
\hline $\begin{array}{l}\text { Groundmass } \\
\text { No. of points }\end{array}$ & $\begin{array}{r}99.3 \\
743\end{array}$ & $\begin{array}{r}99.7 \\
755\end{array}$ & $\begin{array}{r}89.0 \\
791\end{array}$ & $\begin{array}{r}99.9 \\
692\end{array}$ & $\begin{array}{r}99.9 \\
525\end{array}$ & $\begin{array}{r}77.4 \\
660\end{array}$ & $\begin{array}{r}99.8 \\
603\end{array}$ & $\begin{array}{r}94.6 \\
814\end{array}$ & 513 \\
\hline $\begin{array}{l}\text { counted } \\
\text { Texture }\end{array}$ & $\begin{array}{l}\text { aphyric/ } \\
\text { trachytic }\end{array}$ & $\begin{array}{l}\text { aphyric/ } \\
\text { trachytic }\end{array}$ & $\begin{array}{l}\text { porphyritic/ } \\
\text { hyalopilitic }\end{array}$ & $\begin{array}{l}\text { aphyric/ } \\
\text { trachytic }\end{array}$ & $\begin{array}{l}\text { aphyric/ } \\
\text { hyalopilitic }\end{array}$ & $\begin{array}{l}\text { porphyritic/ } \\
\text { cryptocrystalline }\end{array}$ & $\begin{array}{l}\text { aphyric/ } \\
\text { trachytic }\end{array}$ & $\begin{array}{l}\text { porphyritic/ } \\
\text { trachytic }\end{array}$ & $\begin{array}{c}\text { seriate/ } \\
\text { hypidiomorphic }\end{array}$ \\
\hline
\end{tabular}


Table 2. Chemical analyses and modes of volcanic and hypabyssal intrusive rocks, Spirit Lake East quadrangle-Continued

\begin{tabular}{|c|c|c|c|c|c|c|c|c|}
\hline Map No. & 28 & 29 & 30 & 31 & 32 & 33 & 34 & 35 \\
\hline $\begin{array}{l}\text { Field sample } \\
\text { number }\end{array}$ & $2 E 42 A$ & $8 E 168 \mathrm{~A}$ & $1 \mathrm{E} 70$ & $2 \mathrm{E} 12 \mathrm{~A}$ & $8 \mathrm{E} 199 \mathrm{~A}$ & $8 \mathrm{M} 70 \mathrm{~A}$ & $9117 \mathrm{~B}$ & $1 \mathrm{E} 68$ \\
\hline $\begin{array}{l}\text { Latitude } \\
\text { Longitude }\end{array}$ & $\begin{array}{l}46^{\circ} 16^{\prime} 23^{\prime \prime} \\
122^{\circ} 03^{\prime} 11^{\prime \prime}\end{array}$ & $\begin{array}{l}46^{\circ} 16^{\circ} 06^{\prime \prime} \\
122^{\circ} 02^{\prime} 50^{\prime \prime}\end{array}$ & $\begin{array}{c}46^{\circ} 15^{\prime} 44^{\prime \prime} \\
122^{\circ} 01^{\prime} 10^{\prime \prime}\end{array}$ & $\begin{array}{c}46^{\circ} 15^{\prime} 05^{\prime \prime} \\
122^{\circ} 00^{\prime} 39^{\prime \prime}\end{array}$ & $\begin{array}{c}46^{\circ} 15^{\prime} 24^{\prime \prime} \\
122^{\circ} 03^{\circ} 43^{\prime \prime}\end{array}$ & $\begin{array}{c}46^{\circ} 15^{\circ} 56^{\prime \prime} \\
122^{\circ} 05^{\prime} 10^{\prime \prime}\end{array}$ & $\begin{array}{c}46^{\circ} 15 \cdot 42^{\prime \prime} \\
122^{\circ} 068^{\prime \prime}\end{array}$ & $\begin{array}{l}46^{\circ} 15^{\prime} 55^{\prime \prime} \\
122^{\circ} 01^{\prime} 31^{\prime \prime}\end{array}$ \\
\hline Map unit & Tad & Tia & $\mathrm{Ta}$ & Td & $\mathrm{Tt}$ & $\mathrm{Td}$ & Td & $\mathrm{Td}$ \\
\hline Rock type & $\begin{array}{l}\text { Quartz } \\
\text { diorite }\end{array}$ & Andesite & Andesite & Dacite & $\begin{array}{c}\text { Dacitic } \\
\text { welded tuff }\end{array}$ & Dacite & Dacite & Dacite \\
\hline Method & $\mathrm{XRF}$ & $\mathrm{XRF}$ & $\mathrm{RR}$ & $\mathrm{XRF}$ & $\mathrm{XRF}$ & $\mathrm{XRF}$ & $\mathrm{XRF}$ & $\mathrm{RR}$ \\
\hline $\begin{array}{l}\mathrm{SiO}_{2} \\
\mathrm{TiO}_{2} \\
\mathrm{Al}_{2} \mathrm{O}_{3} \\
\mathrm{Fe}_{2} \mathrm{O}_{3} \\
\mathrm{FeO} \\
\mathrm{MnO} \\
\mathrm{MgO} \\
\mathrm{CaO} \\
\mathrm{Na}_{2} \mathrm{O} \\
\mathrm{K}_{2} \mathrm{O} \\
\mathrm{P}_{2} \mathrm{O}_{5} \\
\mathrm{H}_{2} \mathrm{O}+ \\
\mathrm{H}_{2} \mathrm{O} \\
\mathrm{CO}_{2}\end{array}$ & $\begin{array}{c}58.0 \\
1.27 \\
18.0 \\
3.99 \\
3.20 \\
0.14 \\
2.21 \\
6.76 \\
4.36 \\
0.80 \\
0.22 \\
0.70 \\
0.27 \\
<0.02\end{array}$ & $\begin{array}{c}58.4 \\
1.0 \\
16.2 \\
1.92 \\
5.42 \\
0.12 \\
2.60 \\
6.51 \\
3.60 \\
0.99 \\
0.34 \\
2.15 \\
0.89 \\
0.02\end{array}$ & $\begin{array}{c}60.4 \\
0.91 \\
16.3 \\
3.0 \\
2.9 \\
0.13 \\
1.8 \\
4.5 \\
4.6 \\
1.8 \\
0.28 \\
0.80 \\
1.2 \\
0.04\end{array}$ & $\begin{array}{c}63.0 \\
0.62 \\
15.5 \\
1.90 \\
3.36 \\
0.13 \\
1.48 \\
4.40 \\
4.49 \\
1.28 \\
0.25 \\
1.91 \\
0.72 \\
0.03\end{array}$ & $\begin{array}{c}63.8 \\
0.70 \\
13.5 \\
3.17 \\
2.55 \\
0.16 \\
0.65 \\
5.04 \\
3.21 \\
0.50 \\
0.14 \\
4.83 \\
1.72 \\
0.06\end{array}$ & $\begin{array}{c}64.6 \\
0.69 \\
13.6 \\
1.59 \\
3.90 \\
0.15 \\
0.86 \\
4.50 \\
3.38 \\
0.89 \\
0.19 \\
3.78 \\
1.34 \\
0.10\end{array}$ & $\begin{array}{c}64.9 \\
0.52 \\
13.5 \\
1.82 \\
3.61 \\
0.15 \\
0.89 \\
4.03 \\
3.44 \\
1.18 \\
0.18 \\
3.82 \\
2.10 \\
0.08\end{array}$ & $\begin{array}{c}66.3 \\
\\
14.7 \\
1.8 \\
2.4 \\
0.13 \\
0.72 \\
2.7 \\
4.6 \\
2.2 \\
0.15 \\
0.89 \\
0.41 \\
1.5\end{array}$ \\
\hline Total & $\overline{99.81}$ & $1 \overline{00.43}$ & $\overline{98.75}$ & $\overline{99.36}$ & $\overline{99.95}$ & $\overline{99.57}$ & $1 \overline{00.39}$ & $\overline{99.02}$ \\
\hline
\end{tabular}

Analyses recalculated volatile-free and normalized to 100 percent

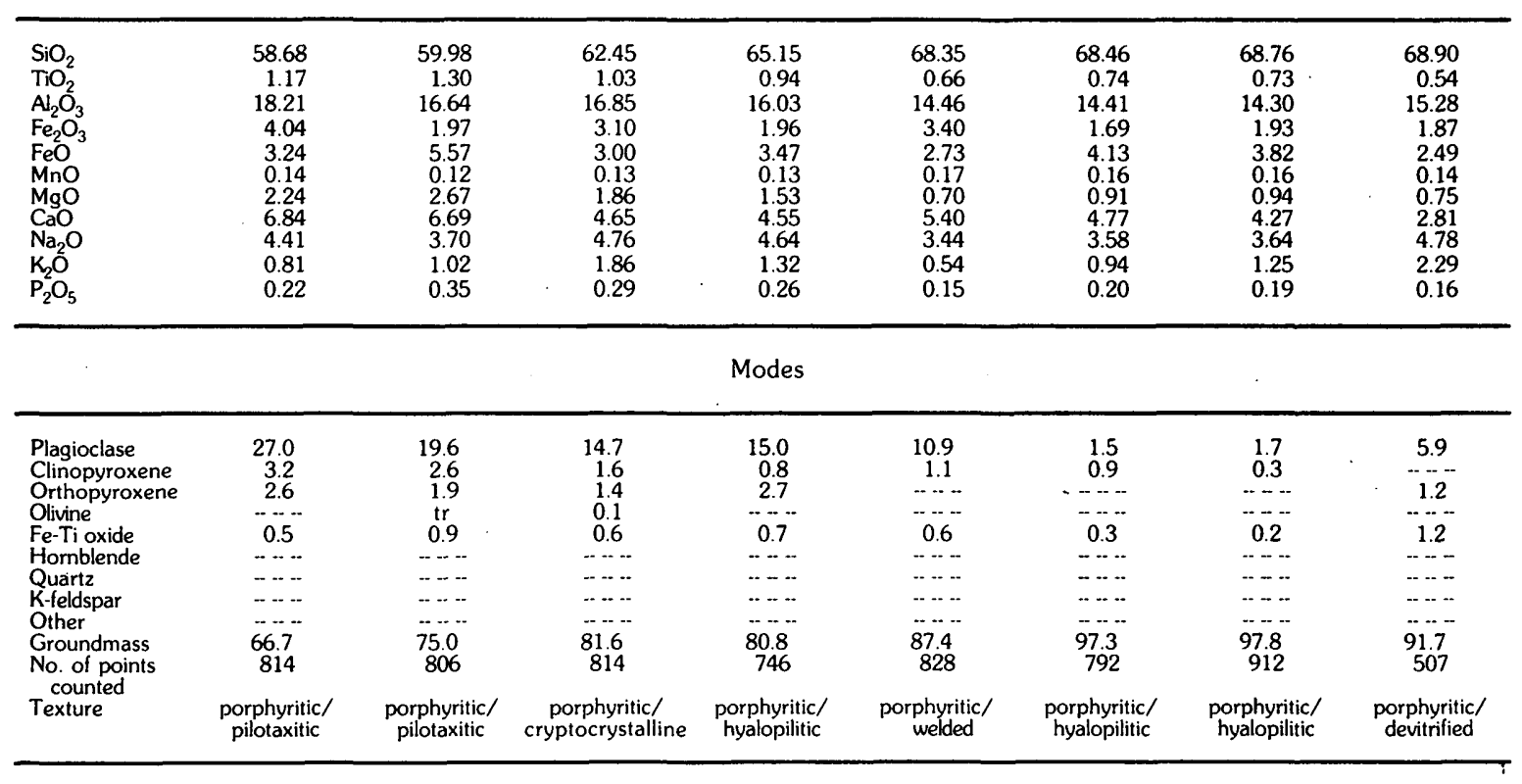

* U.S. G.P.0.:1993-301-077:80030 